\title{
Indie Weerbaar Polemic and the Radicalization of Sarekat Islam (1917-1918)
}

\author{
Miftahul Habib Fachrurozi \\ Department of History Education, Faculty of Teacher Training, Universitas Siliwangi, \\ Tasikmalaya, West Java, Indonesia \\ *Corresponding Author: miftahul.habib@unsil.ac.id \\ DOI: https://doi.org/10.14710/ihis.v4i2.9095
}

\begin{abstract}
This article analyses the polemic relationship between the formation of Indie Weerbaar and the radicalization of the Sarekat Islam. The organization later protected the Dutch East Indies from the effects of the First World War. The support from Sarekat Islam initiated polemics with left groups within the Sarekat Islam. This article was written using the historical method. It emphasizes on the using of primary sources in the form of writing records from some prominent figures of Sarekat Islam. The results show that the Sarekat Islam decentralization policy implemented by the Governor-General of Idenburg resulted in the organization's leadership losing control of its agencies. Abdoel Moeis' involvement in the Indie Weerbaar committee triggered a polemic against leftist figures in Sarekat Islam, especially Semaoen. Semaoen managed to take advantage of the formation polemic of Indie Weerbaar to increase his influence and popularity. Semaoen even succeeded in influencing the Sarekat Islam congress participants to support more radical organizational policies such as the labor movements. In other hand, Semaoen also succeeded in influencing other Sarekat Islam leaders, including Tjokroaminoto, to become more radical through the organization of Radicale Concentratie in Volksraad. Thus, it can be seen that the polemic on the formation of Indie Weerbaar led to the radicalization of the Sarekat Islam movement.
\end{abstract}

Received:

October 6, 2020

Revised:

November 26, 2020

Accepted:

December 6, 2020

Keywords: Indie Weerbaar; Radicalism; Sarekat Islam; Semaoen; Leftist Figures.

\section{Introduction}

The Dutch East Indies in the early twentieth century experienced a situation that had never occurred in previous centuries. The adoption of ethical politics by Queen Wilhelmina created complex socio-political dynamics in the colony. Ethical politics includes policies on irrigation, transmigration, and education. Ethical Policy aimed at improving the welfare of the native population in the Dutch East Indies and education is the central program of this policy (Fachrurozi, 2019, p. 19). Therefore, many new schools were established by the colonial government to support this program. This expansion of education was inseparable from the modernization of the bureaucratic system in the Dutch East Indies which gave rise to the need for natives with literacy skills (McVey, 2009, pp. 12-13). Therefore, the colonial government tried to expand access to education for the native people to meet the needs of administrative personnel. 
It was this expansion of access to modern education that gave rise to a new social class in the Dutch East Indies, namely the educated natives.

Educated natives are one of the main actors of the national movement. The word "movement" can be interpreted as all kinds of actions carried out by modern organizations towards the direction of Indonesian independence (Suhartono, 2001: 4). From the end of the first decades of the twentieth century, various modern organizations founded by educated natives began to appear. Boedi Oetomo is considered to be the pioneer of the national movement organization. Boedi Oetomo was founded on May 20, 1908 in Batavia (Anderson, 2000, p. 503). This organization was founded by a group of Javanese priyayi (aristocrats) who were currently studying at School tot Opleiding van Indische Aarsten (STOVIA). Boedi Oetomo's main program is to support increased educational opportunities and promote trade and industry for Javanese (Pols, 2019, p. 97). The establishment of Boedi Oetomo inspired educated natives to take part in the national movement.

Boedi Oetomo has different character with Sarekat Islam. Boedi Oetomo is a moderate organization which only focus on advancing an exclusive community group. Especially when the elderly like dr. Radjiman and Dwidjosewojo are in control of the organization, so Boedi Oetomo is more concerned with education for Javanese and Madurese priyayi only and not the interests of the common native people (Utama, 2017, p. 63). This was also seen in the results of the first congress which only focused on social and educational issues and was not involved in political affairs (Nagazumi, 1989, pp. 71-72). In contrast to the Boedi Oetomo, which was dominated by priyayi, the Sarekat Islam consisted of common people from non-priyayi classes such as traders or ordinary people. When Tjokroaminoto joined Sarekat Islam in 1912, this organization began to show the character of the mass movement of the native people. The sociopolitical dynamics in the Dutch East Indies in the second decade of the twentieth century contributed to the development of Sarekat Islam and even contributed to the radicalization of the organization.

Indie Weerbaar was one of the issues that influenced the socio-political dynamics in the Dutch East Indies at that time. What is interesting about the issue of the formation of Indie Weerbaar is the wide attention that has emerged from various movement organizations in the Dutch East Indies towards this issue. This issue also directly exacerbated the conflict of interest among leaders of movement organizations including the Sarekat Islam. Unfortunately, yet there has been study that specifically addresses the relationship between Indie Weerbaar and the development of Sarekat Islam. The study from Ahmad (2014) of the development of the Sarekat Islam and the left movement in Semarang was talking about Indie Weerbaar and Sarekat Islam but has not elaborated further in the relationship between that two. Meanwhile, the research by Winarni \& Widuatie (2015) regarding the political conflict in the Sarekat Islam movement only focuses on discussing political ideological conflicts between the Semaun and Tjokroaminoto, without analysing Indie Weerbaar's polemic and its influence on the radicalization of Sarekat Islam. Another study from Muryanti (2010) mentioned that Indie Weerbaar was one of the factors that caused the discord within the 
Sarekat Islam, but she did not explain its connection with the radicalization of the Sarekat Islam. Based on this background, the authors examining in more depth the relationship between Indie Weerbaar and the radicalization of Sarekat Islam.

\section{Method}

This research uses historical research methods. According to Kuntowijoyo, there are five stages that researchers must take in conducting historical research, which are topic selection, heuristics, verification (source criticism), interpretation, and writing or historiography (Kuntowijoyo, 2013, p. 69). The sources used in this study include primary and secondary sources. Primary sources were obtained from the National Library of Indonesia (PNRI). Meanwhile, secondary sources were obtained from PNRI, the author's collection, and journal articles that are available online. The primary sources are in the form of article which had published from several newspapers, such as Sinar Djawa, Sinar Hindia, and Neratja. Those records give information about some prominent figures such as, Semaoen and Abdoel Moeis. On the other hand, the secondary sources that the author uses are books and scientific journals with related themes that are available both physically and online.

\section{Sarekat Islam in the 1910s}

Sarekat Islam is an organization that has an important role in the national Indonesia movement. Sarekat Islam was originally a security organization called Rekso Roemekso which emerged in Laweyan, Surakarta in 1911. The emergence of Rekso Roemekso cannot be separated from the increasing activity of theft against batik traders in the region. Laweyan is indeed known as one of the most prosperous areas in Surakarta, and it was not surprising that thieves made it a target for criminal acts (Suharto \& Abdurakhman, 2020: 191). Therefore, Rekso Roemekso was established to block the thieves who often interfere with batik trading activities in Laweyan. This organization is led by a batik merchant named Haji Samanhoedi. In addition to conducting deterrence against thieves, Rekso Roemekso also competes and even often involved clashes with the Chinese organization trade in Surakarta named Kong Sing (Simbolon, 2006, p. 260).

Competition with Kong Sing made Samanhoedi try to strengthen Rekso Roemekso position in Surakarta. Rekso Roemekso is not an organization that has a statute and legal status. It raises concerns if at any time the organization may be dissolved by the colonial government. Therefore, Samanhoedi attempted to turn Rekso Roemekso into a legally incorporated organization. With the help of Martodharsono, Samanhoedi managed to contact Tirtoadhisoerjo to help change the status of Rekso Roemekso. Tirtoadhisoerjo, who is known as the father of the national press and has long experience in the formation of modern organizations, succeeded in compiling the statutes of the new organization at the end of 1911 (Ricklefs, 2008, p. 359). At this moment, Rekso Roemekso changed its name into Sarekat Dagang Islam.

Sarekat Dagang Islam is an organization based on a cooperative that aims to promote the trade of its members under the name of Islam (Pringgodigdo, 1994, p. 
4). The idea of a Muslim merchant union was then spread widely to various regions. Due to the wide enthusiasm of the community and for reasons of organizational expansion, in 1912 the Sarekat Dagang Islam was changed to the Sarekat Islam. This change formally occurred on September 10, 1912 (Mustakif \& Mulyati, 2019, p. 11). Changing the name and remove the word "dagang" (trade) indicates if the Sarekat Islam is not only meant for traders, but also for the muslims in general. Since then, many muslims from various backgrounds have joined the Sarekat Islam.

Membership of the Sarekat Islam grew very rapidly. The number of members of the Sarekat Islam Surakarta in August 1912, for example, was estimated at 35,000 people (Shiraishi, 2005, p. 64). Though the number of men residents in Surakarta from various ethnic groups, including Eastern Europe and the foreign as well as a variety of age ranges was estimated at 60,000 people alone. Thus, it can be said that more than half of male natives in Surakarta joined with the Sarekat Islam. Sarekat Islam has entered into various aspects of Javanese life at that time. The rapid growth of the Sarekat Islam also shows that the Sarekat Islam has united various groups, including modernists, traditionalists, traders, and small farmers (McVey, 2009, p. 17). This organization has also begun to expand in other big cities such as Surabaya and Bandung. The Sarekat Islam was thus transformed into a people's organization with socio-political strength to be reckoned with.

The rapid development of Sarekat Islam was caused by several factors. The first factor is the deteriorating socio-economic conditions of the Javanese people. Rapid population growth, accompanied by a decline in economic income, has made people's living standards decline. This issue was successfully exploited by the Sarekat Islam figures. The second factor is the use of newspaper media and mass associations (vergadering) (Shiraishi, 2005, pp. 66-67). During the early days of the Sarekat Islam in Surakarta, this organization had an official newspaper called Sarotomo. Other branches of the Sarekat Islam also have mass media including Oetoesan Hindia which was published in Surabaya, Sinar Djawa in Semarang, Kaoem Moeda in Bandung, and Pantjaran Warta in Batavia (Maters, 2003, pp. 107-108). This newspaper generally contains the writings of local Sarekat Islam figures. Meanwhile, vergadering was carried out by gathering large numbers of people to listen to political speeches of Sarekat Islam figures. This vergadering was even able to gather mass in the number of tens of thousands.

The main character in the early development of Sarekat Islam was Haji Oemar Said Tjokroaminoto. He is the son of a Javanese aristocrat from Madiun, East Java. Tjokroaminoto studied at Opleiding School voor Inlandsche Ambtenaar (OSVIA), Magelang. After graduating, he had served as a clerk at Kepatihan Ngawi Regency as well as Wedana in the same area. He only lasted three years as a wedana and clerk and then decided to move to Surabaya to return to study at Burgerlijk Avondschool (BAS), a vocational school owned by the colonial government. After hearing the news of Boedi Oetomo congress was being held in Yogyakarta in October 1908, Tjokroaminoto and his colleagues at BAS intended to establish a branch of the organization in Surabaya. Tjokroaminoto himself is the chairman of the Surabaya branch of the Boedi Oetomo, 
which consists of BAS students (Achdian, 2017: 41). However, just like the Boedi Oetomo central organization controlled by the elderly, the Surabaya branch of the Boedi Oetomo also suffered a similar fate. Since the first congress of Surabaya branch of the Boedi Oetomo in December 1908, the organization's leadership has shifted to Raden Pandji Tjokrodiprodjo. Since then, the role of Tjokroaminoto and his colleagues from BAS has slowly faded away. Even after graduating from BAS, Tjokroaminoto preferred to work at a factory in Rogojempi rather than wrestling back into the world of organization.

Tjokroaminoto experience in leading a movement organization is this that makes the Sarekat Islam leaders believe that he can save the organization (Achdian, 2017, p. 45). In May 1912, Tjokroaminoto joined Sarekat Islam at the invitation of the leader of the Sarekat Islam Surakarta, Haji Samanhoedi (Winarni \& Widuatie, 2015, p. 221). The arrival of Tjokroaminoto was originally a strategy of the Sarekat Islam leadership to avoid the attempt to freeze Sarekat Islam by the Surakarta Resident. The effort to freeze is considered only binding to the Sarekat Islam organization with the statute of association made by Tirtoadhisoerjo (Shiraishi, 2005, p. 65). Therefore, Tjokroaminoto was asked to draw up the new statute of association for the new Sarekat Islam domiciled in Surabaya. Tjokroaminoto succeeded in compiling the statutes for Sarekat Islam in Surabaya and at the same time moving the center of the organization's activities to the port city in the East of Java Island.

Since then Tjokroaminoto has emerged as one of the most important figures of the Sarekat Islam. His expertise as an orator became a special attraction for commoners to join the Sarekat Islam. The vergadering that was often carried out by Sarekat Islam was able to be used by Tjokroaminoto and other figures to strengthen the socio-political position of the Sarekat Islam. Vergadering was so successful even with soon became the main characteristic of the movement of the Sarekat Islam. Apart from that, the propaganda carried out through the organization's various newspapers also encouraged the rapid development of Sarekat Islam. Sarekat Islam was the only organization at that time that was able to gather tens of thousands of people to listen to speeches or political speeches of its figures. Tjokroaminoto is undeniably the main primadonna in every vergadering held by Sarekat Islam.

Sarekat Islam was originally an organization that focused on socio-economic issues, but some vergadering held by Sarekat Islam indicate if the organization has the potential to threaten the power of the colonial government. Governor-General Idenburg began to realize the possible threat from the rapid development of Sarekat Islam. Idenburg felt the need to enact a special policy to reduce the threat of Sarekat Islam to the colonial government. He then asked the deputy advisor for indigenous affairs, Adolf Rinkes to observe the development of the Sarekat Islam, including its potential threats to the colonial government (Drewes, 1961, pp. 429-430). At the suggestion of Rinkes, Idenburg then decided that Sarekat Islam was not allowed to have a national organization. Sarekat Islam is only allowed to stand in a limited manner at the local level (Poesponegoro \& Notosusanto, 2010, p. 344). Even this local branch of Sarekat Islam is only allowed to operate in very limited areas. The only institution 
that functions connect between the various branches of Sarekat Islam is the Centraal Sarekat Islam. However, the Centraal Sarekat Islam has very limited authority and does not have a command function over regional branches of Sarekat Islam.

After successfully inhibiting the development of Sarekat Islam nationally, Idenburg then thought of ways to control the organization's political orientation. Idenburg considered that the colonial government needed an intermediary in the Sarekat Islam to control the development of the organization. Therefore, he asked for help from Rinkes again to realize his plan. Based on Rinkes' assessment, the only figure who could be trusted as an intermediary between the colonial government and the Sarekat Islam was Tjokroaminoto. Rinkes considered that Tjokroaminoto was the only Sarekat Islam figure who was educated and could be trusted by the colonial government (Shiraishi, 2005, p. 97). Thanks to the help of the Rinkes and his popularity, Tjokroaminoto was able to assume the position of chairman of the Centraal Sarekat Islam. Meanwhile, Samanhoedi got the position of honorary chairman of the Centraal Sarekat Islam, a position that did not have any power.

Idenburg's attempts to control the Sarekat Islam were successful at first. The existence of Tjokroaminoto as the leader of the Centraal Sarekat Islam is considered capable of controlling the actions of Sarekat Islam members in various regions. Tjokroaminoto himself did not appear to have any intention to confrontation against colonial government. Under the leadership of Tjokroaminoto, Sarekat Islam was directed to become a "nationalistic-democratic-religious-economic" movement (Ahmad, 2014, p. 224). Even in one of his speeches, he emphasized that Sarekat Islam was not a political movement but an economic movement that seeks to revive the trading spirit of the Indonesian nation. By making Sarekat Islam a non-political organization, threats to the colonial government could be minimized.

However, Idenburg's efforts to eliminate the radical potential and the political orientation of the Sarekat Islam began to fail slowly. Tjokroaminoto started couldn't handle all branches of Sarekat Islam under his control. The Sarekat Islam branches developed beyond Tjokroaminoto's control. The members follow orders Sarekat Islam over the local leaders rather than a command from Centraal Sarekat Islam. The decentralized organizational structure made the potential for divisions within the Sarekat Islam very strong. The regional Sarekat Islam branches often confronted the Centraal Sarekat Islam. The confrontation and conflict between the Centraal Sarekat Islam and the Sarekat Islam branches began to intensify in the final half of the second decade of the twentieth century.

\section{The Discourse on the Establishment of Indie Weerbaar}

The political situation in the Dutch East Indies cannot be separated from major events that occurred globally. Similarly, the socio-political dynamics that second decade of the twentieth century. There were various major events taking place in Europe, especially the Netherlands, which influenced this dynamic. The major events that occurred globally at that time and had a broad effect on political life in the Dutch East Indies were First World War. First World War began in 1914 and ended in 1918. This 
war was the culmination of tensions between European countries at the beginning of the century the twenty (Abdullah, 2015, pp. 510-511). The assassination of the AustroHungarian crown prince, Franz Ferdinand in Sarajevo being main caused by this war. The Kingdom of the Netherlands declared itself as a neutral party in this war, however, the involvement of neighboring countries in Europe made the Netherlands have to remain alert to the possible adverse effects of this war.

First World War also had a broad impact on the Dutch East Indies. Shipping between Europe and the Indies disrupted because of war (Ricklefs, 2008, p. 370). This war disrupted the export and import activities of the Dutch East Indies. The colonial government spending on military and defence also increased. The colonial government was worried that the war in Europe would spread to colonies in the Dutch East Indies. On the other hand, the budget for people's welfare has decreased (Furnivall, 2009, p. 422). This reduction in the budget for the welfare of the people had a direct impact on the deterioration of the socio-economic conditions of the Dutch East Indies. First World War indirectly had many negative impacts on the Dutch East Indies.

The colonial government began to realize that the First World War was a serious threat. Japan was considered the main threat to the security of the Dutch East Indies. Japan's victory over Russia a decade earlier increased its aggressiveness in controlling some of the regions in Asia. It was feared that Japanese aggression would reach the Dutch East Indies. However, the colonial government soon realized that the number of available military personnel would be insufficient if the Dutch East Indies were to be attacked by Japan (Nagazumi, 1989, p. 161). Massive recruitment to cover the number of personnel is also impossible. Apart from being able to result in a drastic increase in the military budget, the number of Dutch people in the Dutch East Indies at that time was quite small. This condition prompted the colonial government to seek alternative solutions to protect the Dutch East Indies from possible attacks by the enemy. The alternative solution in question is the formation of the bumiputra militia, better known as Indie Weerbaar.

Discourse formation of Indie Weerbaar become one of the ingredients of debate among the movement's organization during the middle of the second decade of the twentieth century. Indie Weerbaar is a bumiputra militia that is expected to be able to protect the Dutch East Indies from the possible direct impact of First World War. The proposal for the formation of the Bumiputra militia has emerged since 1907. However, this discourse has begun to become a hot topic since an article entitled Indie Weerbaar was written by a General Staff of the Colonial Army named Major J. van der Weijden. The article appeared in the newspaper Java Bode in 1914. He viewed that the formation of the bumiputra militia would encourage unity between the colonial government and the bumiputra and strengthen solidarity between races (Dijk, 2013, p. 272). Concerns about the threat of war in the Dutch East Indies made Van der Weijden's article immediately received a wide reaction from various groups including the movement organization. 
Boedi Oetoemo is one of the organizations that openly support the formation of Indie Weerbaar. This support was decided in a meeting in Semarang on September 13, 1914. Boedi Oetoemo leaders viewed that protecting the homeland was an obligation for the native people and the formation of civilian militias was a concrete form of carrying out this obligation (Nagazumi, 1989, pp. 162-164). Boedi Oetoemo even sent some administrators to carry out campaigns to support the formation of Indie Weerbaar to various regions in Java from June to July 1915 (Dijk, 2013, p. 280). This support is inseparable from Boedi Oetomo's efforts to take advantage of the issue of the formation of Indie Weerbaar to re-show its existence in the arena of national movements (Poeze, 2008, p. 108). Apart from Boedi Oetomo, support for the formation of Indie Weerbaar also came from some figures from the Centraal Sarekat Islam such as Tjokroaminoto and Abdoel Moeis.

Abdoel Moeis is a figure who has a strong influence in the Sarekat Islam beside of Tjokroaminoto. Moeis comes from a noble Minangkabau family. He received his education up to the Hollandsche Burger School (HBS). Even Abdoel Moeis received his education at STOVIA even though he failed to complete his education due to opposing the school policy. After being expelled from STOVIA, Moeis worked as a clerk in the colonial government's Ministry of Education and Culture (Azmi, 1982, p. 7). Aboel Moeis joined Sarekat Islam at the direct request of Tjokroaminoto.

The peak of Abdoel Moeis' career in Sarekat Islam occurred when he was elected as deputy chairman of the Centraal Sarekat Islam in 1916 (Noer, 1982, p. 125). This position made Abdoel Moeis the second person in Sarekat Islam after Tjokroaminoto. Apart from being active in the Sarekat Islam, Moeis is also known as a productive journalist and has written for several newspapers such as Preanger Bode, De Express, and Neratja (Rahzen, et al., p. 2007). Moeis' influence the Sarekat Islam was also influenced by his non-Javanese background. The presence of Moeis in the ranks of the Sarekat Islam leadership is considered to represent the aspirations of the Sarekat Islam branches outside Java. Abdoel Moeis is also a central figure in Sarekat Islam who is the main supporter of the formation of Indie Weerbaar. He even made campaign to West Java in August 1916 for gathered support from local branch of Sarekat Islam to Indie Weerbaar formation (Dijk, 2013, p. 281).

Contrary to the wishes of a number of movement organizations, the people of the Dutch East Indies had their doubts about the idea of establishing Indie Weerbaar. The campaigns carried out by the Boedi Oetomo figures and Abdoel Moeis for example, were not fully supported by the indigenous people. Abdoel Moeis stated that only twenty branches (out of about one hundred and twenty branches) of Sarekat Islam agreed with Indie Weerbaar. Among Europeans, they also doubted the loyalty of the militias and feared that the armed natives could turn against them. Realizing that the resistance to Indie Weerbaar was quite strong, the colonial government decided to carry out propaganda. They took advantage of the Commissie voor Volkslectuur (People's Literature Commission) to hold public lectures about Indie Weerbaar (Dijk, 2013, p. 276). This effort did not appear to be completely successful and in fact worsened relations between the Dutch East Indies and Japan. This was due to the bad reportage published 
by newspapers in the Dutch East Indies against Japan. Even so, the colonial government still insisted on realizing the formation of Indie Weerbaar.

In other hand, the formation of Indie Weerbaar was greeted positively by the governor-general of Idenburg's successor, Van Limburg Stirum. He is considering forming an institution that can accommodate the exchange of ideas for organizations that support the formation of Indie Weerbaar. As a follow-up, the Indie Weerbaar Committee was formed at the initiative by the governor-general (Simbolon, 2006, p. 284). The Committee is officially established in July 1916. The establishment of the Committee Indie Weerbaar marks the official support of the colonial government against the proposed formation of Indie Weerbaar to maintain defence and security of the Indies of the possible impact of the First World War.

The Indie Weerbaar Committee immediately launched a campaign to attract the sympathy of the people and the Dutch kingdom. Their efforts received support from a former KNIL officer named W. V. Rhemrev. Rhemrev suggested that the committee meet directly with Queen Wilhelmina in the Netherlands to discuss the idea of forming the bumiputra militia. In January 1917, the Indie Weerbaar Committee sent envoys to campaign in the Netherlands and especially to seek support from Queen Wilhelmina. This envoy consisted of six members, which are W.V. Rhemrev, Pangeran Ario Koesoemodiningrat representing the Princes' Union, Raden Toemenggoeng Danoesoegondo (Regent's Union), Mas Ngabehi Dwijosewojo (Boedi Oetoemo), F. Laoh (Minahasa Association), and Abdoel Moeis representing Centraal Sarekat Islam (Poeze, 2008, p. 108). The Indie Weerbaar Committee arrived in the Netherlands in early March 1917. Their arrival was greeted directly by the Queen of the Netherlands, the Minister of the colony, and the Dutch Parliament.

Unfortunately, the committee does not work as expected. The delegates were busier campaigning for the interests of their respective organizations rather than fighting for the formation of Indie Weerbaar. Dwijosewojo for example, he met with various political groups to explain the Boedi Oetomo's line of struggle. Abdoel Moeis even had time to make the Dutch public excited by stating that the main objective of the Centraal Sarekat Islam was self-government for the Dutch East Indies (Simbolon, 2006, p 286). The Kingdom of the Netherlands and the Parliament also considered that the formation of Indie Weerbaar was not an urgent matter. As a result, the issue of the formation of Indie Weerbaar is slowly being forgotten. On the other hand, many regional branches of Sarekat Islam strongly opposed the discourse of establishing Indie Weerbaar. This discourse has even become one of the triggers for the development of left groups within the Sarekat Islam that have contributed to the radicalization of the organization.

\section{Indie Weerbaar Polemic and Radicalization of Sarekat Islam}

The development of the Sarekat Islam is increasing rapidly from time to time, not always having a positive impact on the organization. This development was not matched by the strong control of the Centraal Sarekat Islam over all branches of the Sarekat Islam. This has resulted in each branch having its political orientation and steps 
which are often contrary to the policies of the Centraal Sarekat Islam in general. The Idenburg policy, which prohibited the formation of a national Sarekat Islam organization, began to have an impact. This condition made the seeds of the radicalrevolutionary movement begin to grow and spread within the Sarekat Islam.

One branch of the Sarekat Islam that has a revolutionary movement is the Semarang branch. Sarekat Islam Semarang has a close relationship with the Indische Sociaal-Democratische Vereeniging (ISDV). The revolutionary activities of the Sarekat Islam Semarang increased when the October Revolution happened in Russia in October 1917. This revolution provided both the impetus and the inspiration for the Sarekat Islam Semarang figures to act more radically and revolutionarily (Rutgers, 2012: 15). On the other hand, the condition of the people of Semarang at that time was quite concerning. Socio-economic inequality and the emergence of bubonic plague increasingly make people suffer (Gie, 1999, pp. 7-11). These conditions made the radical and revolutionary seeds of the Sarekat Islam Semarang increasingly flourish. This indirectly also sharpens the difference between the political views of the Sarekat Islam Semarang with the Centraal Sarekat Islam which tends to be more moderate. This difference in political views has made the conflict between the two camps even more visible.

Semaoen was the most prominent figure of the Sarekat Islam Semarang. His reputation as an influential political figure began when he led the Vereeniging van Spoor en Tramweg Personeel (VSTP) or the railway workers organization when he was 14 years old. He is the protégé of the founder of ISDV, Henk Sneevliet (Achdian, 2011: 45). Sneevliet is known as a figure who introduced communism to the national movement. Sneevliet is also directing Semaoen and VSTP to move more radically to improve the conditions of the natives which were oppressed by colonialism. On May 6, 1917, the Sarekat Islam Semarang underwent a reorganization. Semaoen was appointed as chairman of the Sarekat Islam Semarang. The appointment of Semaoen as chairman of the Sarekat Islam Semarang was also a sign of a change in the orientation of the organization with a more radical style (Muryanti, 2010, p. 26). Semaoen then became the main actor in the campaign against the formation of Indie Weerbaar which was supported by the Centraal Sarekat Islam.

Semaoen views that the formation of Indie Weerbaar only benefits the capitalists and harms the native people. He conveyed in an article published in Sinar Hindia. He said that the people's condition was getting more and more difficult. The people's difficulties are caused by the price of goods that are getting more expensive and the tax burden getting heavier. On the other hand, kaoem oeang (the capitalists) are actually getting richer with abundant wealth and assets. For Semaoen, it was the assets and wealth of the capitalists that the colonial government wanted to protect and not the safety of the native people. In short, Indie Weerbaar actually made the people poorer and made the capitalists even richer (Semaoen, 1918a).

Semaoen continued his criticism of the plan to form Indie Weerbaar. According to Semaoen, the colonial government spent millions of guilders only to protect the capitalists and not for the interests of the common people. Ironically, the colonial 
government often did not have a budget for the welfare of the people, but instead provided a large budget for the formation of the bumiputra militia or Indie Weerbaar (Semaoen, 1918d). Semaoen also revealed other reasons for the formation of Indie Weerbaar, which are strengthening the position of the Netherlands in the Dutch East Indies, protecting Dutch capital and investment, and supporting the exploitation by capitalists against the people (Semaoen, 1918b). For Semaoen, Indie Weerbaar was clearly formed only for the interests of the capitalists and not for the benefit of the common people.

The main target of Semaoen's criticism was the colonial government. For Semaoen, colonial government ignoring the plight of the native people. On the other hand, the colonial government proposed the formation of Indie Weerbaar using a people's tax. Semaoen viewed that the colonial government had an interest in protecting companies in the Dutch East Indies by taking advantage of the formation of Indie Weerbaar. On the other hand, these companies are what make the native people suffer a lot. According Semaoen, with the formation of Indie Weerbaar, the native people have to protect those who have been oppressing them at the risk of their own lives. The formation of Indie Weerbaar was also considered to be repressive to the movement to weaken the struggle of the native people to improve the fate of their nation.

These various reasons have made Semaoen firmly reject Sarekat Islam's involvement in the formation of Indie Weerbaar even though Abdoel Moeis is part of the Indie Weerbaar Committee representing the Centraal Sarekat Islam. Semaoen even accused that Abdoel Moeis has been bought to fight against anti-Weerbaar and was taken to influence the Hindia's people to agree on the Indie Weerbaar (Semaoen, 1918c). Semaoen's attack on Abdoel Moeis made the relationship between the Sarekat Islam Semarang and the Centraal Sarekat Islam getting worse.

Abdoel Moeis responded to these criticisms. As a representative of the Central Sarekat Islam in the Indie Weerbaar Committee, he needs to respond to these criticisms. Moeis explained that Indie Weerbaar is a means to achieve the concept of real resilience for the native people. Resilience is meant to have independence in terms of economy, intellect, and personality (Noer, 1982: 132). Also, in an article in Neratja he said that Indie Weerbaar had moved the hearts of the Dutch to pay more attention to the state of the Indies land (Moeis, 1917). For Moeis, the Indie Weerbaar campaign motivate the Dutch people to encourage the Dutch kingdom to make a policy that could improve the conditions of the natives in the Dutch East Indies.

Abdoel Moeis' involvement in the Indie Weerbaar Committee was his political strategy to gain the trust of the Dutch kingdom. He saw an opportunity that the support of the native people for the formation of Indie Weerbaar could be a tool to persuade the kingdom and the Dutch parliament to expand the political rights of the native people (McVey, 2009, p. 24). Moeis hopes that the formation of Indie Weerbaar will also be accompanied by the formation of a forum or parliament that can fight for the interests of the native people in government (Elson, 2009, p. 29). This parliament would later be named Volksraad. Volksraad was expected to be able to encourage the 
involvement of the native people in making decisions that influenced the running of the government in the Dutch East Indies. At the same time, the colonial minister Thomas Bastian Pleyte was also submitting a proposal to the Dutch Parliament regarding the formation of a representative institution in the Dutch East Indies (Rohmadi \& Warto, 2019, p. 168). Governor-general Van Limburg Stirum himself was also known as a figure who supported the full autonomy of the Dutch East Indies, including the effort to establish a representative institution on the colony lands. Through a long process, Volksraad was finally officially founded on May 18, 1918 in Batavia. However, Volksraad was not a purely legislative institution as Moeis had hoped. Volksraad only functioned as an advisory institution without any legislative powers that could directly influence colonial government policies.

The polemic and sharp differences in political views between Abdoel Moeis and Sarekat Islam Semarang then continued in the Sarekat Islam National Congress held in Jakarta on 20-27 August 1917. At the congress, Semaoen attract the participants to refuse the formation of Indie Weerbaar (Gie, 1999, p. 27). Abdoel Moeis countered Semaoen's maneuver by proposing the dismissal of Semaoen and other Sarekat Islam Semarang figures. Moeis considered that the Sarekat Islam Semarang would prioritize the teachings of socialism and put aside Islamic values in their struggle. The Congress also discussed the attitude of the Sarekat Islam to the proposed formation of Volksraad. Semaoen strongly objected to the formation of Volksraad. He even scorned Volksraad as a comedy for not having legislative power (Yuliati, 1994: 54).

In the end, the results of the congress decided to accommodate both conflicting parties. The congress participants rejected both Semaoen's and Abdoel Moeis' suggestions. Semaoen remains part of the Sarekat Islam Semarang while Sarekat Islam continues to support the formation of Indie Weerbaar and Volksraad. The Congress also established the principle of self-government (zelf-bestuur) as well as agreed on the struggle against "evil capitalism" (Pringgodigdo, 1994, p. 8). Semaoen was satisfied with the results of the congress. Moreover, he received support from nearly half of the participants in the second Sarekat Islam national congress against the formation of Indie Weerbaar. On the other hand, Abdoel Moeis said that the results of the second national congress were too socialist.

A year later, the Third Sarekat Islam National Congress was held in Surabaya from 29 September to 6 October 1918 (Gie, 1999, p. 35). The congress was attended by 3,000 people from 87 branches of Sarekat Islam in various regions. The congress participants this time tended to support Semaoen's radical attitude. The results of the congress said if Sarekat Islam will oppose the government colonial if the government protects capitalism in the East Indies. The Congress also agreed to organize the workers in the struggle against "evil capitalism". Centraal Sarekat Islam has previously had the wings of the labor organization called Servants Mortgage Boemipoetera (PPPB) that was established in 1916. While Sarekat Islam Semarang affiliated with VSTP equally radical orientation. The two sides agreed to form the Unity Movement of Labor (PPKB) as a forum for movement for trade unions in the Dutch East Indies while preventing possible clashes between PPPB and VSTP (Maters, 2003, p. 174). The formation of 
PPKB shows a change in the vision of the Sarekat Islam movement which prioritizes socialist issues rather than religious issues.

The issue of organizing the workers was not the only outcome of the congress that was agreed upon. The Congress also agreed to refuse the formation of Indie Weerbaar (Ahmad, 2014, p. 229). Abdoel Moeis surprisingly also agreed to Indie Weerbaar's refusal. This change in Abdoel Moeis' attitude is quite surprising because previously he was the main supporter of the formation of Indie Weerbaar within Sarekat Islam. Meanwhile, Semaoen was elected as commissioner of the Central Java branch of Centraal Sarekat Islam. The results of The Third Sarekat Islam National Congress reflect if the Sarekat Islam began shortly to take the path of radical struggle.

Semaoen's success in serving as commissioner of the Central Java branch of Centraal Sarekat Islam further strengthened his position within the Sarekat Islam. After the congress, Semaoen massively called on the workers to fight against "the lust of kaoem oeang [the capitalists] who exploit the workers" (Semaoen, 1917). The labor movement is embodied in the protests until the strike that was supported by Sarekat Islam Semarang. These actions were aimed at the government and company owners in Semarang to fulfil the political and economic rights of the workers. The proposed political and economic rights include severance pay, changes in working hours, salary increases, food allowances, and leave issues (Yuliati, 1994, p. 50). It was this alignment of Semaoen and Sarekat Islam Semarang with the interests of the workers that made their radical movement very popular and received wide support from the workers.

Semaoen's campaign against Indie Weerbaar, his success influenced the outcome of the congress, and his increasing popularity among workers made Tjokroaminoto feel that his position as chairman of the Centraal Sarekat Islam was under threat (Shiraishi, 2005, p. 140). He decided to take a radical path to maintain his position as the most dominant figure in the Sarekat Islam. Therefore, Tjokroaminoto tried to stir up the spirit of democracy and new socialism within the Sarekat Islam. He even helped encourage the strikes as an epic struggle Sarekat Islam to show partiality to the poor people. Tjokroaminoto also decided to support the outcome of the third national congress and withdrew support for Indie Weerbaar to maintain his position as chairman of the Centraal Sarekat Islam. These political steps show that Semaoen's actions were indirectly successful in provoking Tjokroaminoto to bring Sarekat Islam to a more radical movement.

Tjokroaminoto's radical path is also evident in his political maneuvers within Volksraad. He was elected as a member of the Volksraad by the colonial government in 1918 (Rutgers, 2012, p. 12-13). In Volksraad, Tjokroaminoto led a political wing known as the Radicale Concentratie. Radicale Concentratie is a political wing that demands an expansion of Volksraad's political function as a full legislative institution (Rohmadi \& Warto, 2019, p. 170). Apart from Tjokroaminoto, the leader of Central Sarekat Islam who is involved in Radicale Concentratie is Abdoel Moeis. At the end of 1918, Radicale Concentratie submitted a motion to the Dutch empire to implement their demands. Unfortunately, the motion was rejected by the Dutch empire so that the expansion of Volksraad's political function was nevertheless carried 
out. Nevertheless, the Radicale Concentratie political maneuver led by Tjokroaminoto has shown a radical form of struggle within Volksraad's body.

The results of the second and third Sarekat Islam National Congresses in 19171918 indicated a radical trend. This, of course, is inseparable from Semaoen's ability to influence congress participants in responding to various ongoing socio-political issues. Semaoen also able to take advantage of the Indie Weerbaar polemic to strengthen his political position and influence in the Sarekat Islam. Semaoen succeeded in strengthening his bargaining position in the eyes of the leader of Centraal Sarekat Islam, HOS Tjokroaminoto, while simultaneously attacking Abdoel Moeis, who was his political opponent. The campaign against Indie Weerbaar succeeded in increasing Semaoen's popularity and influence within the Sarekat Islam. On the other hand, Tjokroaminoto felt the need to take the Sarekat Islam to a more radical path to maintain its influence within the Sarekat Islam. The Indie Weerbaar polemic also marked the initial phase of the politicization and ideology of the Sarekat Islam movement (Abdullah, 2015, p. 511). Thus, it can be seen that the Indie Weerbaar polemic has radicalized the Sarekat Islam movement as a whole.

\section{Conclusion}

The radicalization of the Sarekat Islam was heavily influenced by external factors. One of the external factors that contributed the most to the radicalization of Sarekat Islam was the discourse on the formation of Indie Weerbaar. Sarekat Islam initially supported the formation of the bumiputra militia by sending Abdoel Moeis to the committe However, the committee has been criticized by the left within the Sarekat Islam led by Semaoen. Semaoen succeeded in taking advantage of the discourse against the formation of Indie Weerbaar to increase his influence within the Sarekat Islam. Semaoen even succeeded in influencing other members of the Sarekat Islam, including Tjokroaminoto, to act more radically in fighting for the fate of the native people. Semaoen's success in spreading radical ideas within Sarekat Islam shows that the discourse of rejection of the formation of Indie Weerbaar has radicalized the Sarekat Islam movement as a whole.

\section{References}

Abdullah, T. (2015). Kees van Dijk, Hindia Belanda dan Perang Dunia I, 1914-1918. Wacana, 16 (2), 510. https://doi.org/10.17510/wacana.v16i2.388

Achdian, A. (2011). “Orang Muda” dalam politik: Dinamika pergerakan antikolonial di Indonesia awal abad ke-20. Prisma, 2, 11-50.

Achdian, A. (2017). Sarekat Islam sebagai kelanjutan Boedi Oetomo:H.O.S. Tjokroaminoto dan awal kebangkitan nasional di Kota Surabaya, 1908 - 1912. Jurnal Sejarah, I (I), 30-51. https://doi.org/10.26639/js.v1i1.51

Ahmad, T. A. (2014). Sarekat Islam dan gerakan kiri di Semarang 1917-1920. Jurnal Sejarah dan Budaya, 8 (2), 225-231. https://doi.org/10.17977/sb.v8i2.4778

Anderson, B. (2000). Saat kelam saat gemilang: Transposisi pada pemikiran nasionalis Indonesia awal. In B. Anderson (Ed.), Kuasa kata: Jelajah budaya-budaya 
politik di Indonesia (pp. 499-563). Yogyakarta: Mata Bangsa.

Azmi. (1982). Abdul Muis. Jakarta: Depertemen Pendidikan dan Kebudayaan.

Dijk, K. van. (2013). Hindia Belanda dan Perang Duna I 1914-1918. Jakarta: KITLVJakarta \& Banana.

Drewes, G. (1961). D.A. Rinkes; A note on his life and work (Met portret). Bijdragen Tot de Taal-, Land- En Volkenkunde, 117 (4), 417-435.

Elson, R. E. (2009). The idea of Indonesia: Sejarah pemikiran dan gagasan. Jakarta: Serambi Ilmu Semesta.

Fachrurozi, M. H. (2019). Politik etis dan bangkitnya kesadaran baru pers bumiputra. Bihari, 2 (1), 13-25.

Furnivall, J. S. (2009). Hindia Belanda: Studi tentang ekonomi majemuk. Jakarta: Freedom Institute.

Gie, S. H. (1999). Di bawah lentera merah. Yogyakarta: Yayasan Bentang Budaya.

Kuntowijoyo. (2013). Pengantar ilmu sejarah. Yogyakarta: Tiara Wacana.

Maters, M. (2003). Dari perintah halus ke tindakan keras: Pers zaman kolonial antara kebebasan dan pemberangusan. Jakarta: Hasta Mitra.

McVey, R. (2009). Kemunculan komunisme Indonesia. Depok: Komunitas Bambu. Moeis, A. (1917, September 29). Soeara Dari Negeri Belanda. Neratja, p. 5.

Muryanti, E. (2010). Muncul dan pecahnya Sarekat Islam di Semarang 1913-1920. Paramita: Historical Studies Journal, 20 (1).

https://doi.org/10.15294/paramita.v20i1.1056

Mustakif, M. K., \& Mulyati, M. (2019). Sarekat Dagang Islam (1905-1912): Between the savagery of Vereenigde Oostindische Compagnie (VOC) and The independence of Indonesia. International Journal of Nusantara Islam, 7 (1), 1-17.

Nagazumi, A. (1989). Bangkitnya nasionalisme Indonesia: Budi Utomo 1908-1918. Jakarta: Pustaka Utama Grafiti.

Noer, D. (1982). Gerakan modern Islam di Indonesia 1900-1942. Jakarta: Pustaka Jaya.

Poesponegoro, M. D., \& Notosusanto, N. (2010). Sejarah nasional Indonesia Jilid V. Jakarta: Balai Pustaka.

Poeze, H. A. (2008). Di negeri penjajah: Orang Indonesia di Belanda (1600 - 1950). Jakarta: Penerbit KPG.

Pols, H. (2019). Merawat bangsa: Sejarah pergerakan para dokter Indonesia. Jakarta:

Penerbit Buku Kompas.

Pringgodigdo, A. K. (1994). Sejarah pergerakan rakyat Indonesia. Jakarta: Dian Rakyat.

Rahzen, dkk, T. (2007). Tanah air bahasa. 2007: I:BOEKOE.

Ricklefs, M. C. (2008). Sejarah Indonesia modern: 1200-2008. Jakarta: Serambi Ilmu Semesta.

Rohmadi, N., \& Warto, W. (2019). Volksraad (People Council): Radicale Concentratie Political Arena and National Fraction, 1918-1942. Jurnal Humaniora, 31 (2), 166. https://doi.org/10.22146/jh.v31i2.30505

Rutgers, S. J. (2012). Sejarah pergerakan nasional. Yogyakarta: Ombak.

Semaoen. (1917). Nasibnja kaoem boeroeh di Hindia Belanda. Sinar Djawa, p. 1.

Semaoen. (1918a, September 7). Anti Indie Weerbaar I. Sinar Hindia, p. 1. 
Semaoen. (1918b, September 10). Anti Indie Weerbaar II. Sinar Hindia, p. 1.

Semaoen. (1918c, September 11). Anti Indie Weerbaar III. Sinar Hindia, p. 1.

Semaoen. (1918d, September 14). Anti Indie Weerbaar V. Sinar Hindia, p. 1.

Shiraishi, T. (2005). Zaman bergerak: Radikalisme rakyat di Jawa 1912-1926. Yogyakarta: Grafiti Press.

Simbolon, P. T. (2006). Menjadi Indonesia. Jakarta: Penerbit Kompas.

Suharto, A., \& Abdurakhman. (2020). The Sarekat Islam in Surakarta. International University Symposium on Humanities and Arts, 190-193.

Suhartono. (2001). Sejarah pergerakan nasional: Dari Budi Utomo sampai proklamasi 19081945. Yogyakarta: Pustaka Pelajar.

Utama, W. S. (2017). Nasionalisme dan Gagasan Kebangsaan Indonesia Awal: Pemikiran Soewardi Suryaningrat, Tjiptomangoenkusumo dan Douwes Dekker 1912-1914. Lembaran Sejarah, 11 (1), 51-70. https://doi.org/10.22146/LEMBARANSEJARAH.23783

Winarni, R., \& Widuatie, M. R. E. (2015). Konflik politik dalam pergerakan Sarekat Islam 1926. LITERASI: Indonesian Journal of Humanities, 5 (2), 216-323.

Yuliati, D. (1994). Semaoen Serikat Buruh dan Pers Bumiputra. Sejarah, 5, 45-60. 